\title{
CHARACTERIZATION OF CROP/LIVESTOCK FARMING SYSTEM IN NEW VALLEY OF EGYPT USING SYSTEM APPROACH
}

\author{
Mona Mohammady I. ${ }^{\text {*, }}$ M.N.M. Abd El-Ati' ${ }^{2}$ H. Hamdon ${ }^{3}$ and Doaa A. Abd El-Salam ${ }^{1}$ \\ 1- Animal Production and Poultry Division, Desert research Center, 2- Department of Animal Production, \\ Assiut University, 3- Department of Animal Production, New Valley University \\ * Corresponding author, Email: monamohammady@hotmail.com
}

\section{SUMMARY}

The current study adopted system approach to characterize the current crop/livestock farming system of small scale farms and to assess its economical efficiency in the New Valley Governorate of Egypt. Four districts were identified, Elkharga, Eldakhla, Baris and Balat. A random sample of 120 farms was taken to represent the four studied districts (30 farms from each district). A questionnaire was designed to cover available production resources, farming activities, variable costs and revenues. Data were collected over the agricultural year from September 2015 to August 2016. Least squares analysis of variance technique using a fixed effects linear model was performed to derive technical coefficients of the considered productive traits for livestock and major crops. Whole farm budget was applied for economical efficiency to determine the overall gross margin (GM) per feddan and benefit/cost ratio $(B / C)$ of the four studied districts. Averages farm size were 7.17 feddan, 8.62 feddan, 4.45 feddan and 10.72 feddan for Elkharga, Eldakhla, Baris and Balat, respectively. Results showed that daily milk yield per head of cow were estimated as $3.29 \mathrm{~kg}, 2.45 \mathrm{~kg}, 1.78 \mathrm{~kg}$ and $1.99 \mathrm{~kg}$ for Elkharga, Eldakhla, Baris and Balat, respectively. On the other hand, the corresponding total milk yield of cow was estimated as $773 \mathrm{~kg}, 515 \mathrm{~kg}, 338 \mathrm{~kg}$ and $398 \mathrm{~kg}$, respectively. Common crops in winter season were Alfalfa, wheat, barley and bean. While in summer season were Elephant grass, darawa, w-corn, cowpeas, fume and cash crops. The obtained values of the farm GM per feddan revealed that farmers of Baris district utilized their limited production resources more efficient than the other studied districts and achieved the highest gross margin per feddan with estimate of LE 15078, while the lowest was Balat district and achieved LE 4188 per feddan. The farm $B / C$ ratio showed that Eldakhla district earned the highest return per unit of money with estimate of 2.22 ratios.

Keywords: System approach, crop/livestock, gross margin, new valley governorate, Egypt

\section{INTRODUCTION}

Crop/livestock farming system, including both crop and livestock components, represents the dominant type of farms in most developing countries. Interaction between both components often has major impact on system productivity and economical efficiency (FAO, 2009). Description of the agriculture farming systems is useful in, particular for, identifying target populations, in the design of development strategies and opportunities for development (Fernandez-Rivera et al., 2004). Cattle, sheep and goat enterprises are one of the main sources of income and play a vital role as source of meat, milk and wool for smallholders in different farming systems of the developing countries (Okereke, 2012).

In Egypt, livestock production systems play an important role within agricultural system in most of the region where about $95 \%$ of the livestock populations are kept in small scale farms (FAOSTAT, 2014). The New Valley governorate, in terms of area, is considered the largest governorate in Egypt, representing approximately $44 \%$ of the total area and located on the Western desert. The target study area contains a variety of small-scale crop/livestock farming system of different farm size and cropping pattern. The production generated from these farms is still low and have to be raised to adequate standards to generate satisfactory income for households living in that area.

Therefore, studying the current crop/livestock farming system in New Valley governorate is an urgent need to recognize the features, components, strengths, weakness, opportunities and constraints within this farming system in order to propose policies and establish the strategies for development. The current study adopted system approach to; 1) characterize and evaluate the current crop/livestock farming system in the New Valley governorate, 2) estimate the technical coefficients of both livestock and crop production performance, 3) estimate the economical efficiency of the system and 4) diagnosis development constraints. Such study would be useful in planning a comprehensive strategy for sustainable development of the New Valley governorate.

\section{MATERIALS AND METHODS}

\section{Study area}

The current study was carried out at the oasis area in the New Valley governorate. The governorate is located on the Western desert of Egypt, $602 \mathrm{~km}$ South West of Cairo and about $226 \mathrm{~km}$ of the Assiut governorate and lay between $25.42^{\circ}$ and $30.47^{\circ}$ East longitude, $22.30^{\circ}$ and $29.30^{\circ}$ North latitude (EEAA 
\& EMU, 2008 ). It shares the borders with the governorates of Menia, Giza and Marsa Matrouh in the North and Assiut, Suhag, Qena and Aswan in the East. Four districts, with respect to major farming schemes, were identified for this study, namely, ElKharga, El-Dakhla, Baris and Balat.

\section{Data collection}

A random sample of 120 farms was selected. Thirty farms were surveyed in each district. A structured questionnaire was designed to cover the available production resources inventory, i.e. labor use and availability, livestock species, numbers and herd composition, land use and tenure, farming activities, socioeconomic data, annual variable costs and revenues. A baseline field survey was performed and comprehensive and detailed data over one agricultural year (2015 -2016) were collected throughout farmers' interviews. Biotic data included the following information: 1) animal production performance; daily milk yield (DMY), lactation period (LP) and total milk yield (TMY), 2) cropping patter and main crops yield and by-product yield per feddan (feddan $=4200 \mathrm{~m}^{2}$ ) and 3) variable costs; which included hired labor, feeding, veterinary services, fertilizers, seeds and machineries in addition to whole farm revenues generated from livestock and crop activities were collected.

\section{Statistical analysis}

Least squares analysis of variance technique were performed using fixed effects General Linear Model procedures of SAS (2004) to derive estimates of technical coefficients for livestock and major crops production performance and to investigate the variations in production resources, livestock and crop performance among the studied districts. The obtained estimates were utilized to determine the economical indicators of the current crop/livestock farming system. The fixed effects linear model used was as follows:

$$
\mathrm{Y}_{\mathrm{ij}}=\mu+\mathrm{a}_{\mathrm{i}}+\mathrm{eij}
$$

Where:

$\mathrm{Y}_{\mathrm{ij}}=$ the observation,

$\mu=$ the overall mean,

$\mathrm{a}_{\mathrm{i}}=$ the effect due to $\mathrm{i}^{\text {th }}$ district, $\mathrm{i}=1,2,3$ and 4 ,

$\mathrm{e}_{\mathrm{ij}}=$ the random effect associated with the individual observation. This element represents all the unidentified factors that may affect the traits under investigation and are not included in the model. The significant differences among means of biological traits were tested using Duncan's Multiple Rang Test (Duncan, 1955).

\section{Financial analysis}

Whole farm budget was adopted as a tool for financial evaluation of the current crop/livestock farming system to estimate the profitability on an annual basis. The monetary values of production are measured in terms of total revenues. This term combines many different farm products into one measure. Revenues were calculated by multiplying the total quantities of the final marketable products by its current farm gate price. While, the variable costs for different activities were calculated by multiplying the quantities of inputs needed by its current market price. FAO (2002) defined whole farm gross margin (GM) as its total revenues less total variable costs attributed to it. To facilitate economical efficiency comparison among the four studied districts of different livestock and crops activities, GM per unit of the limiting production resources was calculated by dividing the whole GM of the farm by the number of resource units used. Gross margin per feddan and per $\mathrm{AU}$ in addition to Benefit/Cost ratio $(\mathrm{B} / \mathrm{C})$ were estimated.

\section{RESULTS AND DISCUSSION}

\section{Salient features}

Results of the field survey derived from the questionnaire showed that traditional crop/livestock farming system is the dominating system and is practiced in a small scale farm size. In the same context, most farmers own a small-scale number of cows, sheep, goats and also some poultry are raised in backyard of the farms to meet the domestic consumption and to spread the risk of losses. Table (1) provides a summary of available production resources inventory in the four studied districts. The summary showed that average family size is nearly the same member of household, while family size in Eldakhla is lower than the other three districts. In contrary, according to CAPMAS (2015) the average size of household member is 4.4 persons which is lower than that found in the studied districts. The average farm size in Balat district is larger than the other three districts with estimate of 10.72 feddan, while Baris is the smallest one. Elkharga and Baris districts own more number of livestock than the other two districts, while Balat district own the smallest herd size.

Table 1. Summary of production resources inventory of the four studied districts

\begin{tabular}{lcccc}
\hline Item & Elkharga & Eldakhla & Baris & Balat \\
\hline Family size (person) & 7.13 & 5.37 & 7.77 & 7.13 \\
Farm size (feddan) & 7.17 & 8.62 & 4.45 & 10.72 \\
Herd size (head) & 44 & 20.4 & 46.4 & 15.3 \\
Feddan/person & 0.99 & 1.60 & 0.57 & 1.50 \\
Animal/person & 6.14 & 3.80 & 5.97 & 2.15 \\
\hline
\end{tabular}

The distribution of herd composition and the equivalent number of animal units are presented in Table (2). In general, it could be observed that sheep and goat constituted more than $60 \%$ of the herd composition in the studied districts. The farmers usually purchased their animals either from the village market or from replacement animals raised on the farm. In the mean time, feed resources in the New 
Egyptian J. Anim. Prod. (2018)

Valley supplied mainly from the indigenous natural vegetation as a principal feed resource for animals, in

addition cultivated forages and crop residues.

Table 2. Herd composition for the four studied districts

\begin{tabular}{|c|c|c|c|c|c|c|c|c|c|c|c|c|}
\hline \multirow{2}{*}{ Species } & \multicolumn{3}{|c|}{ Elkharga } & \multicolumn{3}{|c|}{ Eldakhla } & \multicolumn{2}{|c|}{ Baris } & \multirow[b]{2}{*}{$\mathbf{A U}$} & \multicolumn{3}{|c|}{ Balat } \\
\hline & No. & $\%$ & $\mathbf{A U ^ { * }}$ & No. & $\%$ & $\mathbf{A U}$ & No. & $\%$ & & No. & $\%$ & $\mathbf{A U}$ \\
\hline Native cow & 11.3 & 25 & 11.3 & 6.5 & 32 & 6.5 & 7.4 & 16 & 7.4 & 5.9 & 39 & 5.9 \\
\hline Sheep & 15.9 & 36 & 2.3 & 6.1 & 30 & 0.9 & 21.9 & 47 & 3.1 & 5.4 & 35 & 0.8 \\
\hline Goat & 16.9 & 39 & 2.4 & 7.8 & 38 & 1.1 & 17.1 & 37 & 2.4 & 4.0 & 26 & 0.6 \\
\hline Herd size/farm & 44.1 & 100 & 16 & 20.4 & 100 & 8.5 & 46.4 & 100 & 12.9 & 15.3 & 100 & 7.3 \\
\hline
\end{tabular}

* One animal unit (AU) $=7$ heads of sheep or goat.

Results of the field survey revealed that most of farmers cultivated nearly the same cropping pattern with different cultivated area according to the farm size. Generally, the cropping pattern resulted from the interaction of farmers' objectives, managerial capabilities and financial capacities. Allocation of land for various crops was left to the farmer decision. It is of interest to notice that a major proportion of the cultivated area in studied districts is allocated for green fodder production. Cropping Pattern in the study area are summarized as follows: Winter crops

Alfalfa, wheat, beans and barley, while in summer crops are Elephant grass, darawa, w-corn, cowpeas, fume and cash crops. Table (3) summarize the cropping pattern and percentage of cultivated area for each crop, in the studied districts, where alfalfa is clearly the major field crop in winter season and represented $38 \%, 59 \%, 80 \%$ and $39 \%$, respectively, while darawa is considered the main crop in summer season constitutes $24 \%, 17 \%, 36 \%$ and $1 \%$, respectively.

Table 3. Cropping pattern and cultivated areas (\%) with major field crops in the studied districts

\begin{tabular}{|c|c|c|c|c|c|c|c|c|}
\hline \multirow{2}{*}{ Crop } & \multicolumn{2}{|c|}{ Elkharga } & \multicolumn{2}{|c|}{ Eldakhla } & \multicolumn{2}{|c|}{ Baris } & \multicolumn{2}{|c|}{ Balat } \\
\hline & Area (fed.) & $\%$ & Area (fed.) & $\%$ & Area (fed.) & $\%$ & Area (fed.) & $\%$ \\
\hline \multicolumn{9}{|l|}{ Winter season: } \\
\hline Alfalfa & 2.7 & 38 & 1.76 & 59 & 1.55 & 80 & 4.2 & 39 \\
\hline Wheat & 2.6 & 36 & 3.3 & 38 & 1.4 & 31 & 3.3 & 31 \\
\hline Barley & 1.2 & 17 & 2.2 & 26 & 1.3 & 29 & 0.97 & 9 \\
\hline Beans & 0.6 & 8 & 1.25 & 15 & ---- & & 0.38 & 4 \\
\hline \multicolumn{9}{|l|}{ Summer season: } \\
\hline Elephant grass & 1.2 & 17 & 0.5 & 6 & ---- & & ---- & \\
\hline Darawa & 1.7 & 24 & 1.5 & 17 & 1.5 & 36 & 0.16 & 1 \\
\hline W-corn & 1.2 & 17 & 1.8 & 21 & 1.2 & 34 & --- & \\
\hline Cowpeas & 1.75 & 24 & 0.6 & 7 & --- & & --- & \\
\hline Fume & 0.6 & 8 & 0.12 & 1 & 1.3 & 31 & --- & \\
\hline
\end{tabular}

Socio-economic characteristics

Results of field survey of the studied districts showed that average age of the household member is 40 years old, and $55 \%$ of them have medium age between 27 years to 60 years old and the literacy rate is about $96.8 \%$. This survey indicated that most of household member are young and have the ability to work. The proportions of households who have basic education, high school, graduation and without education were 5.8, 21.8, 69.2 and $3.2 \%$, respectively. Generally, the field survey revealed that, livestock constitute a flexible source of cash flow, supporting farmers to purchase farm inputs and meet other urgent needs, and also a buffer against uncertainty of market price or poor harvest and a way to satisfy social events and ceremonies. In addition, it plays a vital role as a source of meat, milk and wool.

In the studied districts, off-farm jobs, mainly in the public services, enable each family to have a secure source of income. The loss of this job because of retirement or death of the sponsor of the family caused uncertainty at family level, particularly in families without livestock. The field survey proved that livestock and off-farm jobs are considered as a major source of income diversification. The obtained results are in agreement with Alary et al. (2015) who reported that sheep and goats in the New Valley provided farmers with basic cash flow, whereas, cows provided a sort of family insurance. Some farmers cover required feed costs by selling young animals, mainly males between four and six months old.

\section{Current management practices Livestock production}

The majority of farmers in the studied districts maintained flocks in small enclosures connected to the family house. Most of livestock are taken care by family labor, mainly boys. Abd El-Monaime (2014) reported that adult male is usually involved in both cultivating and animal management practices, while women usually taking care of small ruminants. In most cases, cows are served naturally with sire available in the village. Livestock feeding regime mainly based on green fodder crops such as alfalfa in winter, while, in summer livestock are fed on darawa, rice straw and crops by-products, in addition to some concentrates purchased from the market.

Animals are hand milked twice a day, and most of the produced milk goes to family consumption either fresh or in the form of processed milk (cottage cheese and ghee). Surplus fresh milk and/or dairy products are sold at the village market. Vaccinations of the 
herd are given mostly by General Authority of Veterinary Services. Most common vaccinating that given for animals in all the studied districts as follow: Rift Valley Fever and Lumpy Skin disease for cattle, while, Lumpy Skin disease, Foot and Mouth disease and plague for sheep and goat.

\section{Crops production}

The source of irrigation water is obtained mainly from groundwater (wells). Rain is also a margin source of water for the New Valley governorate. Soaking, sprinkling and dripping techniques are the common irrigation systems. Most of farmers use agricultural machinery, particularly, in preparing the soil for cultivation; these equipments are owned by farmers or rented. Most of farmers in the studied districts using organic fertilizer produced at their own farms, in addition to chemical fertilizers.

\section{Technical coefficients \\ Animal production}

Least squares means $(\mathrm{X} \pm \mathrm{SE})$ of milk production traits per head of native cow under the prevailing farming system are presented in Table (4). The overall mean of TMY was estimated as $543 \mathrm{~kg}$. The obtained estimate is lower than those reported by Nigm et al. (1986) of $638 \mathrm{~kg}$, Abdel-Aziz (1993) of $640 \mathrm{~kg}$, Ahmed et al. (1996) of $1088 \mathrm{~kg}$, Ahmed et al. (2000) of $943 \mathrm{~kg}$ and Abdel-Aziz (2015) of 1303 $\mathrm{kg}$ under smallholders. District showed a highly significant effect $(\mathrm{P}<0.01)$ on TMY. These variations in estimates may due to different management practices. Results indicated that cows raised in Elkharga district produced the highest total milk yield $(773 \mathrm{~kg} / \mathrm{head})$ compared to those in the other three districts. These differences may be attributed to higher DMY (3.29 kg) than the other districts in addition, longer lactation period of cows in Elkharga than cows in Eldakhla, Baris and Balat (235 days vs. 210 days, 190 days and 200 days), respectively. On the other hand, cows raised in Baris district are the lowest one with estimate of $338 \mathrm{~kg} / \mathrm{head}$ compared to those in the other three districts.

Table 4. Least squares means $(X \pm S E)$ of milk production performance under the four studied districts.

\begin{tabular}{|c|c|c|c|c|c|c|c|c|c|c|c|}
\hline \multirow{2}{*}{ Classification } & \multicolumn{4}{|c|}{ DMY (kg) } & \multicolumn{4}{|c|}{ LP (day) } & \multicolumn{3}{|c|}{ TMY (kg) } \\
\hline & $\mathbf{N}$ & $\mathbf{X}$ & & $\mathbf{S E}$ & $\mathbf{N}$ & $\mathbf{X}$ & & SE & $\mathbf{N}$ & $\mathbf{X}$ & SE \\
\hline Overall & 653 & 2.50 & \pm & .74 & 653 & 212 & \pm & 20.3 & 653 & $543 \pm$ & 0.57 \\
\hline District & \multicolumn{4}{|c|}{ NS } & \multicolumn{4}{|c|}{ NS } & \multicolumn{3}{|c|}{$* *$} \\
\hline Elkharga & 237 & 3.29 & \pm & 0.18 & 237 & 235 & \pm & 3.3 & 237 & $773^{\mathrm{a}} \pm$ & 60.15 \\
\hline Eldakhla & 137 & 2.45 & \pm & 0.26 & 137 & 210 & \pm & 2.3 & 137 & $515^{\mathrm{a}} \pm$ & 45.42 \\
\hline Baris & 155 & 1.78 & \pm & 0.32 & 155 & 190 & \pm & 4.0 & 155 & $338^{\mathrm{b}} \pm$ & 33.4 \\
\hline Balat & 124 & 1.99 & \pm & 0.42 & 124 & 200 & \pm & 3.3 & 124 & $398^{\mathrm{b}} \pm$ & 30.50 \\
\hline
\end{tabular}

DMY; daily milk yield, TMY; total milk yield, LP; Lactation period.

${ }^{a, b}$ Means within the same column with different superscripts are significantly different $(\mathrm{P}<0.01)$

$* * \mathrm{P}<0.01, \mathrm{NS} ;$ non significant.

\section{Crop production}

The crop yield/feddan is a composite trait resulting from the interaction of natural factors, weed control, rotation design, soil fertility and structure, system of irrigation, seedling rate, cultivation date and timing of each operation. The estimate of crop yield per feddan (technical coefficients) of the major field crops in four districts are presented in Table (5). From the obtained results, Alfalfa considered the major winter crop in all the studied districts. Comparing the average crop yield among the studied districts revealed that Balat district achieved the highest yield of Alfalfa. While, Baris scored the highest yield of Darawa crop in summer season. Eldakhla achieved the highest yield per feddan of Elephant grass during summer season.

Table 5. Average of crops yield per feddan (Ton) under the four studied districts.

\begin{tabular}{lcccc}
\hline Crops & Elkharga & Eldakhla & Baris & Balat \\
\hline Winter season: & & & & \\
Alfalfa & 12.5 & 18.7 & 19.9 & 22.9 \\
Wheat & 3.1 & 3.0 & 0.3 & 3.4 \\
Barley & 3.7 & 0.7 & 3.3 & 2.2 \\
Beans & 1.4 & & --- & 0.4 \\
Summer season: & & 20.0 & ---- & 6.3 \\
Elephant grass & 17.7 & 1.4 & 6.9 & -- \\
Darwa & 2.5 & 8.9 & 3.8 & --- \\
W-corn & 8.0 & 8.3 & ---- & \\
Cowpeas & 3.6 & $r .9$ & \\
\hline
\end{tabular}

\section{Farm budget breakdown}

Breakdown of the whole farm budget for the four studied districts, Elkharga, Eldakhla, Baris and Balat revealed that annual livestock variable costs represented a large proportion of the whole farm variable costs with estimate of $73.8 \%, 57.9 \%, 71.0$ $\%$ and $65.2 \%$. While annual variable costs expenditures of crops production constituted $26.2 \%$, $42.1 \%, 29.0 \%$ and $34.8 \%$ for the corresponding 
districts, respectively. On the other hand, the obtained results showed that annual revenues generated from livestock enterprise constituted $62.9 \%, 43.8 \%, 53.5 \%$ and $53.2 \%$, respectively. These variations among the districts may due to the different objectives of each farmer, animal's biological performance and herd size and composition. It is of interest to observe that live animals sales represented the major source of the whole farm gross output and constituted $33.2 \%, 29.4$ $\%, 37.1 \%$ and $40.3 \%$, respectively. These results indicated that most of farmers in the studied districts having skills in fattening procedures and the expected rewards are more profitable than the other farm products. The breakdown of crop products' results also showed that alfalfa crop is considered the major source of revenues in Elkharga, Eldakhla, Baris and Balat districts and achieved 9.1\%, 24.4\%, 19.3\% and $19.8 \%$, respectively of the whole farm gross output. The current findings have the same trend as the results obtained by Abdel-Aziz (2015).

\section{Economical indicators}

Estimates of economic indicators derived from the whole farm budget are displayed in figure (1). The current study adopted $\mathrm{B} / \mathrm{C}$ ratio (the rewards per unit of money spend on the production operations) as profitability criteria of the current faming system. From profit point of view and at the whole farm level, the obtained values of $\mathrm{B} / \mathrm{C}$ ratio revealed clearly that farms located at Eldakhla district generated higher profits than farms in the other three districts and achieved a ratio of 2.22. While farms located in Elkharga district were the lowest and scored a ratio of 1.74 . These variations of $\mathrm{B} / \mathrm{C}$ ratio may attributed to managerial capability and financial capacities of the farmers. In general, $t$ is markedly observed that, crops enterprise, in all studies districts is more profitable than livestock enterprise which is may due to the poor biological performance of livestock and higher feeding costs. The obtained results revealed that farmers usually direct their available capital resources towards the most profitable enterprise.

In the same context, economical efficiency is considered conclusive criteria of the current system. Since it combines both livestock and cropping enterprise into one economic index. Values of gross margin per unit of limited production resources are displayed in Figure (2). The obtained values of the whole farm gross margin per feddan and also at the cropping enterprise level, revealed that farms located at Baris districts achieved the highest return per feddan of estimates LE 15078 and LE 6322 , respectively. The obtained estimates of GM are higher than those reported by Ahmad et al. (2000) obtained LE 870 and LE 1950 respectively that conducted at small farms in South Al-Tahrir province These results are in agreement with other findings in previous studies as those conducted by Siam et al. (1994), Ahmed (1995), Ahmed et al. (1996), Mahmoud (1997) and Alsheikh et al. (2002). Judging by economical efficiency criteria, farmers of Baris districts utilized their limited production resources more efficient than the other studied districts. This may due to proper management and appropriate allocation of the available production resources.

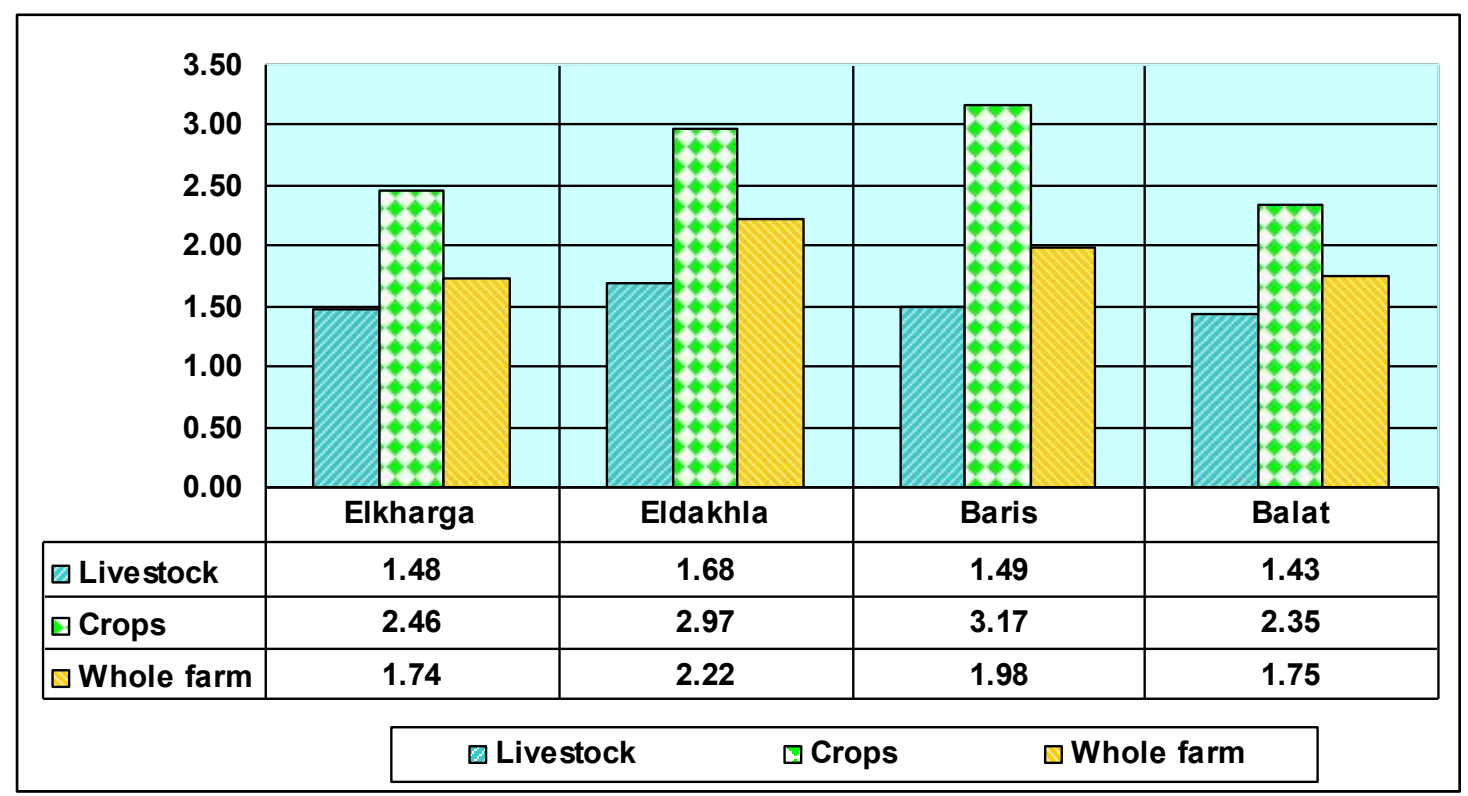

Figure 1. Estimates of $B / C$ ratio for the studied districts. 


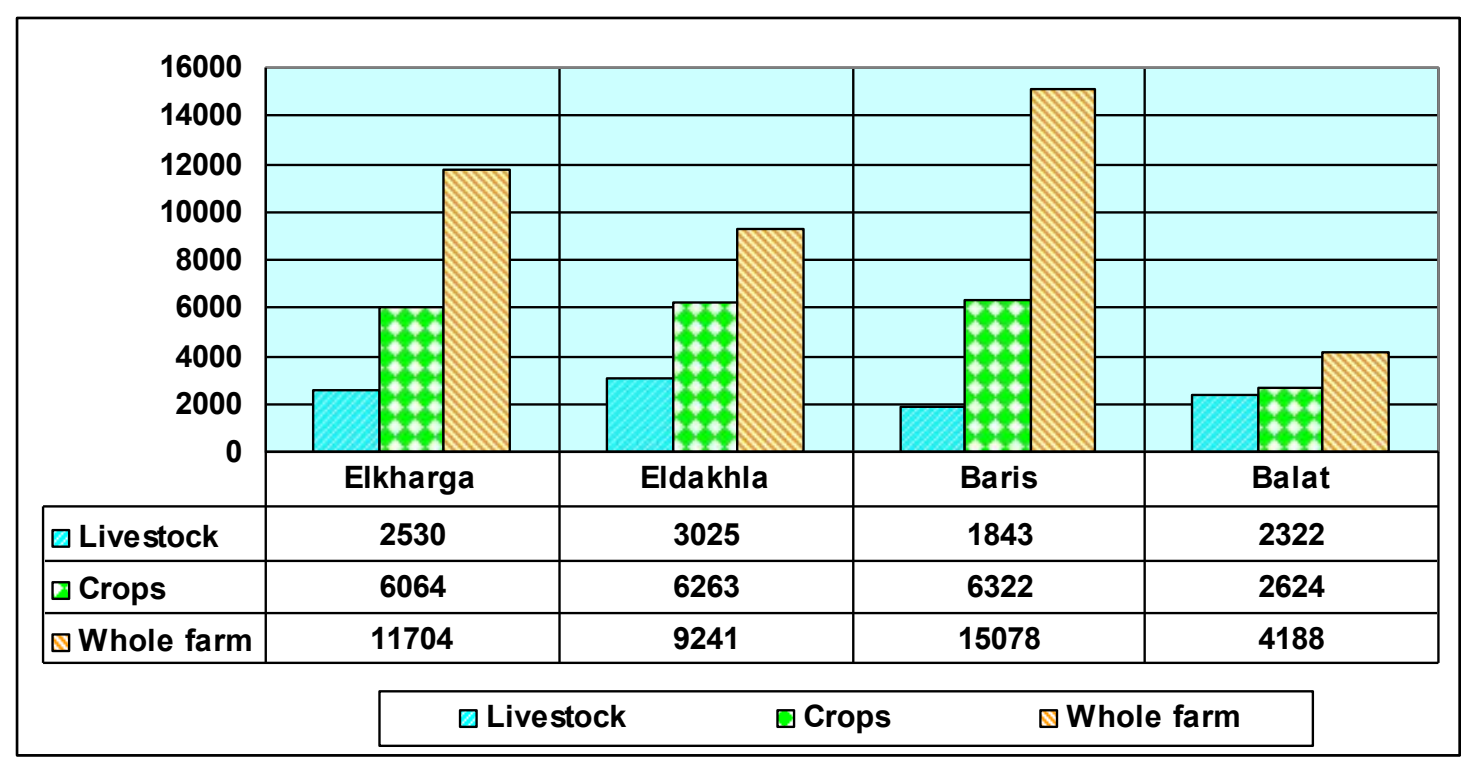

Figure 2. Economic efficiency of the current studied districts

\section{CONCLUSION}

It could be concluded that crop/livestock farming system in New Valley governorate is constrained by many limiting constraints. These constraints represent serious threat to the sustainability of agricultural production. Low productivity of livestock, poor crops yield and limited feed resources are considered the major constraints which faces the current system. Therefore, these findings could be useful for decision makers in planning for comprehensive sustainable development of the New Valley and providing farmers with appropriate and effective technologies to improve the utilization of their limited production resources.

\section{REFERENCE}

Abdel Aziz, A.S., 1993. Production System In: Animal Protein Food System, increasing efficiency of production, processing and marketing. Winrock International Institute for Agricultural Development. Project No. 263-2020, Cairo, Egypt.

Abdel-Aziz, Y.A., 2015. Characterization of crop/livestock production system in reclaimed areas of Egypt. Egyptian J. Anim. Prod., 52(1): 19-29.

Abd El-monaime, M.E.A., 2014. Small ruminant production systems in New Valley. M.Sc. Thesis. Assuit University.

Ahmed, A.M., 1995. Efficiency of Some Livestock Production Systems under Egyptian Agricultural Conditions . Ph . D thesis, Faculty of Agriculture , Cairo Univ ., Egypt . 255pp.

Ahmed, A.M., Bedier, Nayera, Z., M.A.M. Ibrahim, and A.S. Abdel-Aziz, 1996. Efficiency of the current crop/livestock production system in a reclaimed desert area in Egypt. Egyptian J. Anim. Prod., 33: 81-90.
Ahmed, A.M., S. Abo-Baker, R.R. Sadek and A.S. Abdel-Aziz, 2000. Appraisal of the current crop/livestock production system in a new area operated by university graduate in Egypt. Proc. 3rd all Africa Conf. Anim. Agric. \& 11th Conf. Egyptian Soc. Anim. Prod. Alexandria, Egypt, 69 Nov. : 629-633

Alary, V., A. Aboul-Naga, M. El Shafie, N. Abdelkrim, H. Hamdon and H. Metawi, 2016. Roles of small ruminants in rural livelihood improvement - Comparative analysis in Egypt.

Alsheikh, S.M, A.M. Ahmed, H. Mansour and E.S.E. Galal, 2002. Improving crop/livestock production system in a newly reclaimed land in Egypt. Egyptian J. Anim. Prod. 39:147-160.

CAPMS. 2015. Central Agency for Public Mobilization and Statistics. Statistical year book, Cairo.

Dhehibi B., and R. Khaldi, 2008. Demand analysis for dairy products in Tunisia: An econometric approach. Options Méditerranéennes : Série A. Séminaires Méditerranéens; n. 78. pages 397404.

Duncan, D. B., 1955. Multiple range and multiple Ftests. Biometrics. 11:1-42.

EEAA- \& EMU, 2008. State Ministry of Environment and New Vally Governorate.. Report for 2007-2008: Environmental action Plan New Valley Governorate.

FAO. 2002. Production Systems in the Near East Region. A Training Manual for Characterization and Analysis. Food and Agriculture Organization.

FAO., 2009. The state of food and agriculture. Rome 2009. Italy. Pp 180.

FAOSTAT., 2014. Statistical database. Food and Agriculture Organization.

Fernández-Rivera S, I. Okike I, V. Manyong, T. Williams, R. Kruska and S. Tarawali, 2004. Classification and description of the major 
farming systems incorporating ruminant livestock in West Africa.

Mahmoud, M.A., 1997. Study of alternatives of production patterns in the old reclaimed land using mathematical modeling. M.Sc. thesis, Faculty of Agriculture, Cairo university, (Abstr.).

Nigm, A.A., I. Soliman, M.K. Hamed and A.S. Abdel-Aziz, 1986. Milk production and reproductive performance of Egyptian cows and buffaloes in small livestock holdings. Proc. 7th Conf. of Anim. Prod., Sept. 16-18, Egyptian Soc. of Anim. Prod., Cairo, Egypt.

Okereke, C.O., 2012. Socio-Economic Factors Affecting Access and Utilization of Veterinary
Services by Small Ruminant Producers in Izzi Local Government Area of Ebonyi State, NIGERIA. Continental J. Agriculture Economics., 6: 40-45.

SAS, 2004. Statistical Analysis System, SAS User's Guide, SAS Institute Inc., Cary, NC.

Siam, G.M., O.A.Gad, and M.A. El-Deeb, 1994. A multi-objective model for developing the livestock/crop system in old reclaimed land. Final report of project No. CA EC 421 Es 35 (NARP), pp. 1-64.

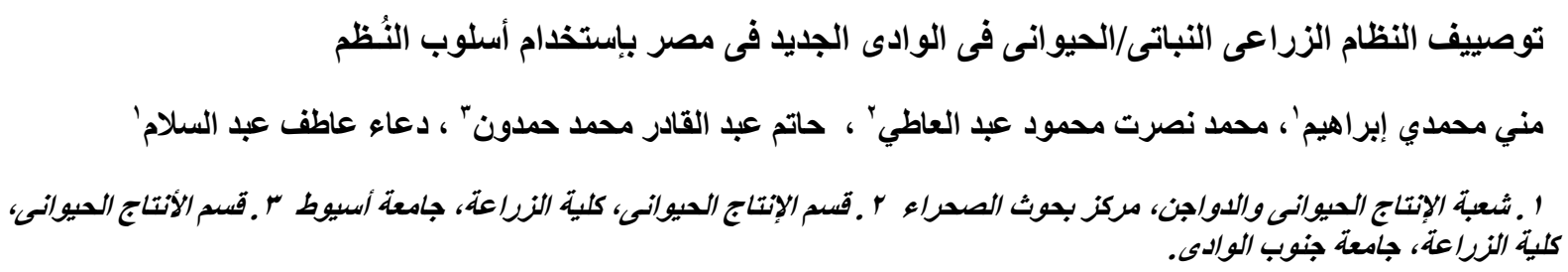

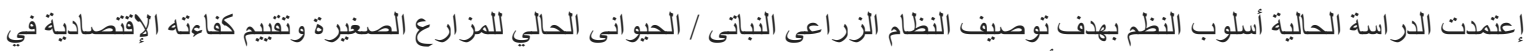

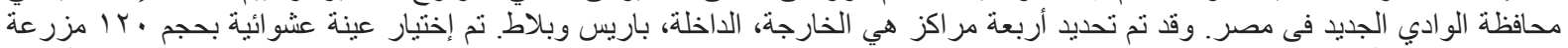

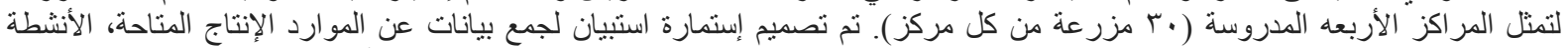

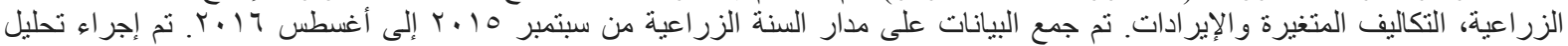

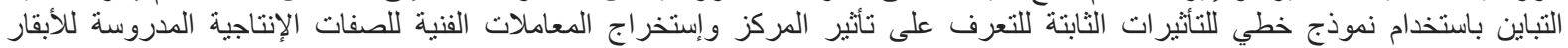

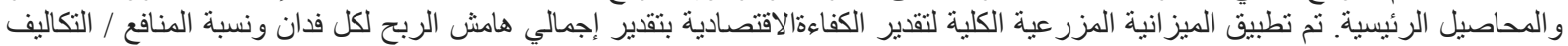

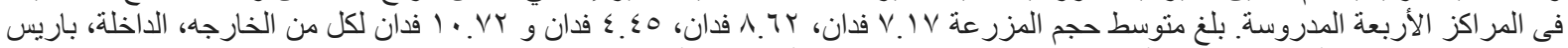

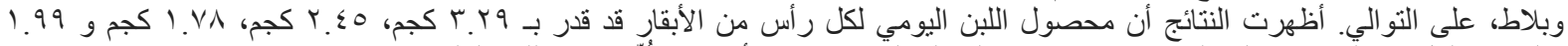

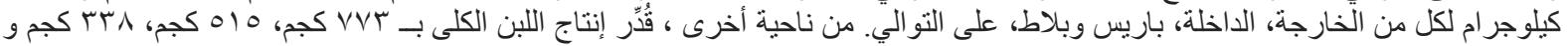

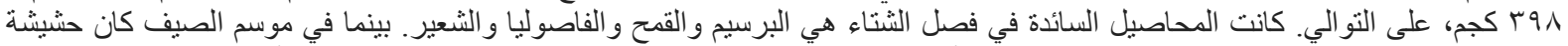

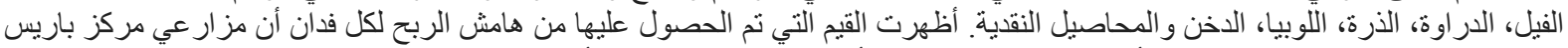

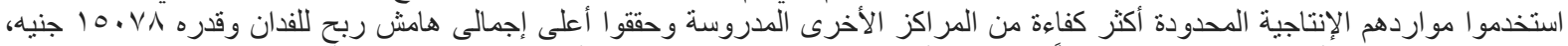

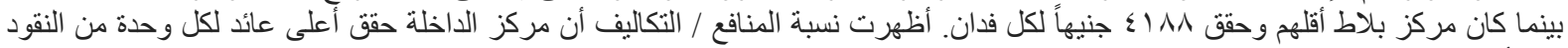

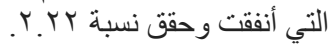

